\title{
STIMULASI PSIKOSOSIAL UNTUK MENDUKUNG PENGELOLAAN EMOSI ANAK KEBUTUHAN KHUSUS
}

\author{
${ }^{1}$ Tasyia Zharifah Arindayani \\ ${ }^{2}$ Dewi Retno Suminar \\ Fakultas Psikologi Universitas Airlangga \\ tasyia.zharifah.arindayani-2014@psikologi.unair.ac.id
}

\begin{abstract}
ABSTRAK
Tujuan dari kajian ilmiah ini adalah untuk menemukan rangsangan psikososial yang dapat membantu pengelolaan emosi anak berkebutuhan khusus. Desain penelitian ini adalah penelitian kualitatif dan metode deskriptif. Partisipan dalam penelitian ini adalah anak berkebutuhan khusus yang membutuhkan penanganan psikologis berupa rangsangan psikososial untuk meningkatkan kemampuan pengelolaan emosinya. Strategi pengumpulan data untuk penelitian ini adalah studi terdokumentasi. Dalam penelitian ini yang melibatkan analisis data penelitian, yaitu reduksi data, penyajian data dan validasi data. Hasil penelitian ini menunjukkan bahwa anak-anak penyandang disabilitas mendapat manfaat dari hubungan positif dan rasa memiliki di rumah, sekolah, dan komunitas. Sayangnya, anak-anak penyandang disabilitas mungkin menghadapi pengucilan sosial dan mengalami stereotip sosial yang negatif. Di sisi lain ada banyak contoh orang tua yang telah mendukung anak-anak mereka melawan segala rintangan dan orang tua ini menunjukkan potensi dan pentingnya dukungan psikososial pengasuh anak untuk perkembangan anak.
\end{abstract}

Kata kunci: psikososial, pengelolaan emosi, anak kebutuhan khusus.

\begin{abstract}
The purpose of this scientific study is to find psychosocial stimuli that can help the emotional management of children with special needs. The design of this study is a qualitative study and a descriptive method. Participants in these studies were children with special needs who needed psychological treatment in the form of psychosocial stimuli to improve their emotional management skills. The data collection strategy for this study is a documented study. In this study, which involves research data analysis, i.e., data reduction, data presentation and data validation. The results of these studies show that children with disabilities benefit from positive relationships and a sense of belonging in their homes, schools, and communities. Unfortunately, children with disabilities can face social exclusion and negative social stereotypes. On the other hand, there are many examples of parents who have overcome all difficulties to support their children, and these parents show the potential and importance of caregiver psychosocial support for their child's development.
\end{abstract}

Keywords: psychosocial, emotional management, special needs children.

\section{PENDAHULUAN}

Anak-anak penyandang kebutuhan khusus (disabilitas dan pengasuhnya sangat rentan terhadap stres (Dickman \& Roux, 2005). Tingkat stres mereka mungkin lebih tinggi jika penyandang disabilitas yang lebih parah tinggal dalam rumah tangga tersebut. Ada bukti yang menunjukkan bahwa hingga
$70 \%$ ibu dan $40 \%$ ayah dari anak-anak dengan disabilitas berat ditemukan dalam keadaan tertekan (Sloper \& Turner, 1993). Tekanan orang tua dan fungsi keluarga berdampak pada kesejahteraan psikososial anak-anak dalam berbagai cara dan mempengaruhi perkembangan kognitif, perilaku dan sosial mereka. Selain itu, hambatan lingkungan dan 


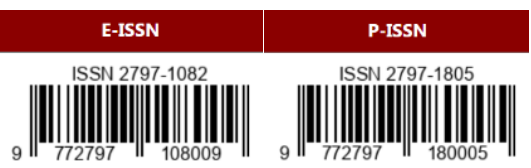

sosial untuk berpartisipasi dalam masyarakat meningkatkan kerentanan sosial keluarga dan anak penyandang disabilitas. Dukungan psikososial bertujuan untuk mengatasi kesejahteraan psikososial anak-anak secara umum. Namun beberapa anak lebih rentan daripada yang lain dan program untuk mendukung anak-anak yang rentan perlu mempertimbangkan hal ini melalui pengarusutamaan disabilitas serta melalui penyediaan intervensi khusus atau adaptasi disabilitas. Dukungan psikososial juga harus diarusutamakan ke dalam program-program untuk mendukung anak-anak penyandang disabilitas dan keluarganya.

Ketidakmampuan untuk secara efektif mengelola stres kronis dan emosi negatif dapat menanamkan rasa putus asa pada anakanak, yang pada gilirannya dikaitkan dengan perilaku impulsif, destruktif, dan tidak pantas secara sosial (Kashani et al., 1997). Prevalensi perilaku yang tidak diinginkan dan berbahaya di kalangan remaja dapat berfungsi untuk melanggengkan suasana emosional ketakutan, permusuhan dan kekerasan yang melingkupi banyak lingkungan sekolah. Meningkatnya laporan media tentang episode kekerasan ekstrem di sekolah baru-baru ini meningkatkan kesadaran masyarakat akan kesehatan emosional anak-anak yang memburuk dan menggarisbawahi kebutuhan untuk menemukan lebih dari sekadar solusi topikal untuk menyelesaikan masalah ini. Emosi stres yang dialami anak-anak seharihari juga mempengaruhi sejumlah reaksi fisiologis yang kompleks dan saling berinteraksi, yang mempengaruhi hampir setiap sistem organ dalam tubuh. Stres emosional diketahui dapat merangsang sistem saraf simpatik dan mengubah pola irama jantung, sehingga mengubah pola aktivitas informasi saraf aferen yang ditransmisikan dari jantung ke otak. Sebaliknya, emosi positif mendorong peningkatan koherensi dalam pola irama jantung, dan pergeseran keseimbangan sympathovagal menuju peningkatan aktivitas parasimpatis (Tiller et al., 1996). Untuk kejelasan, koherensi digunakan di sini untuk menggambarkan tingkat ritme dalam takogram detak jantung. Digunakan dalam pengertian ini, istilah ini menunjukkan distribusi konten daya yang teratur atau konstruktif dalam bentuk gelombang tunggal (autokoherensi). Dengan definisi ini, gelombang sinus yang sempurna mewakili koherensi maksimum yang mungkin. Jadi, semakin mirip gelombang sinus pola irama jantung, dikatakan semakin koheren.

Tujuan penulisan karya ilmiah ini adalah guna mengetahui stimulus psikososial yang bisa mendukung pengelolaan emosi anak kebutuhan khusus. Berdasarkan penjelasan latar belakang di atas, maka peneliti membahas mengenai, "Stimulasi Psikososial untuk Mendukung Pengelolaan Emosi Anak Kebutuhan Khusus."

\section{MET ODE}

\section{Desain Penelitian}

Desain penelitian ini adalah penelitian kualitatif yang menyelidiki dan memahami pentingnya individu atau kelompok orang yang berbeda yang dihasilkan dari masalah sosial (Cresswell, 2016). Penelitian kualitatif umumnya digunakan sebagai penelitian tentang kehidupan, masyarakat, sejarah, perilaku, konsep, atau fenomena. Alasan dipilihnya jenis penelitian ini adalah untuk menemukan dan memahami apa yang melatarbelakangi fenomena yang sulit dipahami tersebut.

Metode yang digunakan dalam penelitian ini adalah metode deskriptif. Implementasinya didasarkan pada filosofi 
post-positivity yang mempelajari keadaan objek secara alami dan merupakan alat penting bagi para peneliti. Tujuan penelitian deskriptif adalah untuk menjelaskan, menjelaskan, menjelaskan, menjelaskan, dan menjawab pertanyaan yang sedang diselidiki.

\section{Partisipan}

Profil partisipan dalam penelitian ini adalah anak-anak dengan kebutuhan khusus yang membutuhkan penanganan secara psikologis. Dalam hal ini berupa stimulus psikososial guna meningkatkan kemampuan pengelolaan emosinya.

\section{Strategi Pengumpulan Data}

Penelitian ini menggunakan salah satu strategi pengumpulan data yaitu studi dokumentasi. Menurut Sugishirono (2016), dokumen merupakan catatan peristiwa masa lalu. Dokumen tersebut dapat berupa teks, foto, atau karya monumental seseorang. Dokumen yang digunakan dalam survei ini adalah jurnal dan buku yang sesuai dengan topik survei dan direduksi menjadi titik data yang sesuai.

\section{Analisis Data}

Pada penelitian ini menggunakan beberapa tahapan analisis data penelitian, yaitu: (1) reduksi data; (2) penyajian data; dan (3) verifikasi data. Pertama, data yang diperoleh kemudian direduksi atau dirangkum dengan memilih hal pokok yang sesuai topik penelitian. Kemudian, data disajikan melalui pola hubungan, sehingga akan semakin mudah dipahami. Terakhir, penarikan kesimpulan atau verifikasi berupa hubungan kausal yang masih bersifat sementara. Bisa berubah apabila tidak ditemukan bukti kuat pada tahap pengumpulan data penelitian berikutnya.

\section{HAS IL PENELIT IAN Memahami Intervensi Psikososial}

Menurut SADC yang dilakukan oleh Hancock (2010), istilah psikososial digunakan untuk menggambarkan, "...hubungan yang erat antara aspek psikologis dari pengalaman kita (yaitu, pikiran dan emosi kita) dan pengalaman sosial kita yang lebih luas (yaitu, pengalaman kita). Hubungan, praktik, tradisi dan budaya). Ini juga memperhitungkan dimensi fisik dan spiritual (sistem nilai, kepercayaan dan kesadaran diri) dari seorang individu"

Psikososial berkaitan dengan interaksi faktor intrinsik individu dan faktor ekstrinsik yang bekerja pada individu itu (Hancock, 2010). Untuk memperluas ini, REPPSI mendefinisikan kesejahteraan psikososial sebagai keadaan di mana individu, keluarga, atau komunitas memiliki kekuatan kognitif, emosional, dan spiritual yang dikombinasikan dengan hubungan sosial yang positif. Keadaan sejahtera ini memotivasi pengembangan keterampilan hidup yang memungkinkan mereka untuk memahami dan terlibat dengan lingkungan mereka, dan membuat pilihan yang sehat yang mengarah pada harapan untuk masa depan. Jadi kesejahteraan mereka dibentuk oleh interaksi faktor intrinsik dan ekstrinsik yang bekerja pada individu, itu semua hal psikososial. Kesejahteraan psikososial dipengaruhi oleh perawatan dan dukungan berkelanjutan yang diterima seseorang dari keluarga, komunitas atau organisasi mereka, yaitu dukungan psikososial mereka. Kerangka SADC mencantumkan tiga domain utama PSS:

1) Dukungan keterampilan dan pengetahuan,

2) Kesejahteraan emosional dan spiritual, dan

3) Kesejahteraan sosial 
Tabel 1: Domain layanan dukungan psikososial

\begin{tabular}{|l|l|}
\hline DOMAIN & DESKRIPSI \\
\hline $\begin{array}{l}\text { Keterampilan dan } \\
\text { pengetahuan } \\
\text { (kognitif) }\end{array}$ & $\begin{array}{l}\text { Keterampilan dan } \\
\text { pengetahuan } \\
\text { mengarah pada } \\
\text { kompetensi dan } \\
\text { kapasitas untuk } \\
\text { mengatasi tuntutan } \\
\text { dan tekanan hidup } \\
\text { dan untuk } \\
\text { mengelola } \\
\text { hubungan dengan } \\
\text { baik. Ini termasuk } \\
\text { pemecahan } \\
\text { masalah, } \\
\text { perencanaan dan } \\
\text { pengambilan } \\
\text { keputusan, } \\
\text { manajemen stres, } \\
\text { negosiasi, } \\
\text { ketegasan, } \\
\text { menggunakan } \\
\text { mekanisme koping } \\
\text { yang sesuai secara } \\
\text { budaya, dan } \\
\text { kemampuan untuk } \\
\text { menilai kekuatan } \\
\text { dalam kaitannya } \\
\text { dengan kebutuhan. }\end{array}$ \\
\hline Kemosional dan & $\begin{array}{l}\text { Kesejahteraan } \\
\text { emosional adalah } \\
\text { kapasitas individu } \\
\text { untuk menjalani } \\
\text { kehidupan yang } \\
\text { penuh dan kreatif } \\
\text { serta fleksibilitas } \\
\text { untuk menghadapi } \\
\text { tantangan hidup }\end{array}$ \\
\hline
\end{tabular}

\begin{tabular}{|c|c|}
\hline DOMAIN & DESKRIPSI \\
\hline & $\begin{array}{l}\text { yang tak terelakkan. } \\
\text { Area intrapersonal } \\
\text { menyangkut } \\
\text { kemampuan } \\
\text { individu untuk } \\
\text { mengetahui dan } \\
\text { mengelola dirinya } \\
\text { sendiri. Ini } \\
\text { menentukan } \\
\text { bagaimana } \\
\text { berhubungan } \\
\text { dengan perasaan } \\
\text { seseorang, } \\
\text { bagaimana perasaan } \\
\text { seseorang tentang } \\
\text { dirinya sendiri dan } \\
\text { apa yang dia wakili } \\
\text { atau lakukan dalam } \\
\text { hidup mereka. Ini } \\
\text { termasuk kesadaran } \\
\text { diri dan rasa harga } \\
\text { diri, kontrol atas } \\
\text { perilaku, keyakinan } \\
\text { realistis, apresiasi } \\
\text { spiritual atau } \\
\text { keyakinan pada } \\
\text { tujuan, kemandirian, } \\
\text { perasaan aman dan } \\
\text { bahagia, } \\
\text { penghargaan } \\
\text { terhadap orang lain } \\
\text { dan harapan untuk } \\
\text { masa depan. }\end{array}$ \\
\hline $\begin{array}{l}\text { Kesejahteraan sosial } \\
\text { (interpersonal) }\end{array}$ & $\begin{array}{l}\text { Area interpersonal } \\
\text { menyangkut } \\
\text { kemampuan untuk } \\
\text { berinteraksi dan } \\
\text { bergaul dengan } \\
\text { orang lain. }\end{array}$ \\
\hline
\end{tabular}




\begin{tabular}{|l|l|}
\hline DOMAIN & DESKRIPSI \\
\hline PSIKOSOSIAL & $\begin{array}{l}\text { Kesejahteraan sosial } \\
\text { mengacu pada } \\
\text { tingkat dan kualitas } \\
\text { interaksi sosial } \\
\text { anak-anak dan } \\
\text { remaja, keluarga } \\
\text { dan masyarakat. Ini } \\
\text { termasuk hubungan } \\
\text { dengan anggota } \\
\text { keluarga dan } \\
\text { kelompok sebaya, } \\
\text { mengembangkan } \\
\text { jaringan sosial, rasa } \\
\text { memiliki } \\
\text { komunitas, } \\
\text { kemampuan untuk } \\
\text { berkomunikasi, } \\
\text { tanggung jawab } \\
\text { sosial, empati dan } \\
\text { partisipasi dalam } \\
\text { kegiatan sosial dan } \\
\text { budaya. }\end{array}$ \\
\hline
\end{tabular}

Sumber: Hancock (2010)

Berisi Selain itu, kerangka kerja mengakui bahwa anak-anak dan remaja dari kelompok usia yang berbeda memerlukan layanan dukungan psikososial yang ditargetkan karena kerentanan yang terkait dengan usia dan kebutuhan perkembangan mereka. Kerangka tersebut membedakan kelompok usia berikut:

- 0-6 tahun: kelompok berisiko tinggi dengan kebutuhan kesehatan, nutrisi dan psikososial tertentu serta kebutuhan perkembangan anak usia dini. Ini adalah kategori usia yang digunakan untuk mengukur kematian anak secara global.
- 7-12 tahun: biasanya anak-anak sekolah dasar dengan pendidikan khusus dan kebutuhan perkembangan dan usia ketika pembelajaran kecakapan hidup harus dimulai.

- 13-17 tahun: biasanya anak-anak dan remaja sekolah menengah. Beberapa akan putus sekolah dan kemungkinan akan melakukan pekerjaan berbahaya, dan akan memiliki kebutuhan khusus dalam hal kesehatan seksual dan reproduksi dan dukungan psikososial serta kebutuhan pendidikan, perkembangan dan keterampilan hidup.

- 18-24 tahun: biasanya pemuda atau dewasa muda di lembaga pendidikan tinggi atau pelatihan keterampilan kejuruan, di luar sekolah atau dalam pekerjaan awal Selain itu ada juga tingkat keluarga, komunitas dan nasional

Namun, kerangka kerja tidak menyebutkan anak-anak penyandang cacat, anak-anak yang hidup dengan anggota keluarga penyandang disabilitas atau pengasuh penyandang disabilitas.

\section{Memahami Disabilitas}

Menurut Organisasi Kesehatan Dunia (2011) melaporkan bahwa 15\% dari populasi dunia hidup dengan setidaknya satu disabilitas (hingga 20\% di rangkaian miskin sumber daya) dan jumlahnya meningkat karena berbagai faktor termasuk peningkatan penyakit kronis seperti HIV (HEARD, 2011; WHO, 2006). Penyandang disabilitas (PWD) karena itu juga telah digambarkan sebagai minoritas terbesar di dunia (PBB, 2008). Data menunjukkan bahwa $80 \%$ penyandang disabilitas di negara-negara berpenghasilan rendah adalah miskin dan memiliki akses terbatas atau tidak sama sekali ke layanan dasar seperti pendidikan dan rehabilitasi. 
Konvensi PBB tentang Hak Penyandang Disabilitas (2009) menyatakan bahwa disabilitas muncul dari persinggungan penyandang disabilitas dengan sikap dan hambatan lingkungan yang mencegah mereka untuk berpartisipasi secara penuh dan efektif dalam masyarakat secara setara dengan orang lain. Istilah disabilitas sering dibicarakan karena memiliki arti yang berbeda bagi orang yang berbeda.

\section{Anak-anak Disabilitas}

Laporan Pemantauan Global EFA 2010 mengungkapkan bahwa 150 juta anak di seluruh dunia memiliki disabilitas dimana sekitar empat dari lima anak penyandang disabilitas berada di negara berkembang (UNESCO, 2010). Selain itu, jutaan anak tinggal di rumah tangga dengan orang tua, tanggungan, pengasuh atau kerabat yang menyandang disabilitas. Selain itu, anak-anak penyandang disabilitas yang bersekolah mungkin memiliki tuntutan yang lebih sedikit pada mereka, dan oleh karena itu mungkin belajar lebih sedikit daripada rekan-rekan mereka yang bukan penyandang disabilitas (Yeo, 2001).

Hubungan antara kemiskinan dan disabilitas telah banyak dijelaskan (Yeo, 2001). Salah satu konsep yang paling umum untuk mengungkapkan keterkaitan ini adalah lingkaran setan kemiskinan dan kecacatan. Lingkaran tersebut menggambarkan bahwa kemiskinan merupakan penyebab dan pendorong kecacatan, yang pada gilirannya, melalui kerentanan sosial, meningkatkan risiko kemiskinan. Anak-anak penyandang disabilitas (dan mungkin mereka yang hidup dengan disabilitas) tidak hanya kecil kemungkinannya untuk bersekolah, tetapi mereka juga memiliki akses terbatas ke layanan kesehatan, lebih mungkin untuk hidup dalam kemiskinan dan berisiko lebih tinggi mengalami pelecehan termasuk pelecehan seksual Karena disabilitas meningkatkan risiko kemiskinan dan menurunkan prospek pendidikan yang pada gilirannya meningkatkan kerentanan sosial termasuk risiko lebih lanjut dari kesehatan yang buruk.

Dalam laporan Departemen Pembangunan Internasional Inggris (DFID) tentang kemiskinan dan kecacatan kronis, Rebbaca Yao menunjukkan bahwa penyandang disabilitas "mengalami diskriminasi sejak lahir, atau sejak saat menjadi cacat" (artinya cacat) (Yeo, 2001). Kelahiran anak cacat mungkin bisa dianggap sebagai tragedi. Dia lebih lanjut menjelaskan bahwa "di mana ada sumber daya yang terbatas, hal itu dapat dilihat sebagai tidak bertanggung jawab secara ekonomi untuk memberikan bagian yang sama dari sumber daya kepada anak cacat yang dianggap tidak mungkin dapat menghidupi keluarga di masa depan" (Yeo, 2001). Dalam kasus kecacatan yang lebih parah, ini bahkan dapat menyebabkan kelalaian atau kematian (Neubert \& Cloerkes, 1994, Ashcraft, 2006). Anak-anak penyandang disabilitas juga dapat digunakan untuk mendapatkan uang dengan mengemis di jalanan (Yeo, 2001) karena disabilitas mereka dapat dimanfaatkan untuk tujuan tersebut.

\section{I S K US I}

Seperti anak-anak lain, anak-anak penyandang disabilitas mendapat manfaat dari hubungan positif dan rasa memiliki di rumah, sekolah, dan komunitas mereka. Sayangnya, anak-anak penyandang disabilitas mungkin menghadapi pengucilan sosial dan mengalami stereotip sosial yang negatif. Di beberapa budaya, kecacatan masih dipahami sebagai 
akibat dari sihir, kerasukan roh jahat atau hukuman spiritual dari 'dewa' (Ansell et al, 2004). Komunitas lain menganggap anakanak dan remaja penyandang disabilitas sebagai yang berkinerja rendah, akibatnya menuntut lebih sedikit dan menawarkan lebih sedikit kesempatan untuk berpartisipasi. Anak-anak penyandang disabilitas lainnya mungkin kehilangan kesempatan untuk berpartisipasi karena orang tua mereka terlalu protektif atau perasaan malu dan bersalah yang dapat menyebabkan mereka menyembunyikan anak-anak mereka dari masyarakat. Selain itu, orang tua sendiri mungkin menganggap anak-anak mereka kurang memiliki keterampilan untuk mencapai sesuatu dengan cara yang efektif. Mereka mungkin memiliki sedikit kepercayaan pada anak-anak mereka dan tidak mendorong mereka untuk mencapai potensi penuh mereka (Saskatchewan School Trustees Association, nd). Anak-anak yang tidak didorong untuk mengeksplorasi lingkungan dan potensi mereka pada akhirnya akan meragukan kapasitas mereka yang dapat menyebabkan harga diri rendah, perasaan rendah diri dan ketidakberdayaan. Di sisi lain ada banyak contoh orang tua yang telah mendukung anak-anak mereka melawan segala rintangan dan orang tua ini menunjukkan potensi dan pentingnya dukungan psikososial pengasuh anak untuk perkembangan anak.

Anak-anak dengan disabilitas punya hak atas perawatan serta dukungan sama seperti rekan-rekan mereka yang berbadan sehat yang mencakup perhatian, perawatan, stimulasi dan dukungan yang konsisten dari pengasuh utama. Selain itu, mereka mungkin memerlukan dukungan dan akomodasi tambahan untuk kebutuhan khusus mereka. Keberhasilan proses attachment memfasilitasi perkembangan identitas dan keamanan anak. Hasrat akan cinta, kasih sayang, dan perhatian tetap ada dalam diri anak saat ia tumbuh menjadi orang dewasa yang sepenuhnya matang. Namun, anak-anak dan remaja penyandang disabilitas mungkin menghadapi risiko menerima dukungan emosional dan sosial yang tidak memadai dari orang-orang di sekitar mereka. Kurangnya dukungan emosional dan sosial yang memadai dapat berasal dari sikap negatif atau kelalaian serta salah tafsir mengenai apa yang dibutuhkan anak-anak penyandang disabilitas. Beberapa kondisi kesehatan mungkin mewajibkan mereka dirawat di rumah sakit sehingga pada akhirnya memisahkan anak dari orang tua mereka ketika keterikatan seharusnya terjadi. Kondisi kesehatan lain tetapi juga pembatasan partisipasi dapat membuat anak bertahan dalam waktu lama di rumah yang mengakibatkan berkurangnya stimulasi dan peluang perkembangan. Selain itu anak-anak penyandang disabilitas mungkin menghadapi tantangan lain, misalnya, hambatan akses fisik ke layanan, kelalaian dan sikap negatif dari teman sebaya dan orang dewasa.

Yang terakhir ini mungkin terkait dengan salah tafsir, mitos, stigma, dan kepercayaan tradisional seputar disabilitas. Reaksi masyarakat terhadap salah tafsir ini dapat mengurangi dukungan sosial dan mendorong pengucilan dan melalui pembatasan ini kesempatan untuk pendidikan, pekerjaan atau partisipasi dalam masyarakat. Faktor-faktor ini memfasilitasi isolasi anakanak penyandang cacat yang berpotensi menyebabkan peningkatan tingkat stres dan harga diri yang lebih rendah (UNICEF, 2005). Isolasi sosial dan pembatasan kesempatan juga dapat menyebabkan kecemasan dan perasaan kurangnya kendali atas situasi kehidupan. Anak-anak penyandang disabilitas 
seringkali memiliki lebih sedikit kesempatan untuk mengeksplorasi lingkungan mereka sebagai akibat dari keterbatasan mereka serta hambatan dalam lingkungan. Selain itu, orang tua atau pengasuh mungkin tidak mampu mengimbangi tantangan ini dan akibatnya anak menerima lebih sedikit stimulasi dan dorongan untuk perkembangannya. Di sekolah, anak-anak penyandang disabilitas lebih cenderung diganggu dan dilecehkan mungkin memiliki jumlah teman yang terbatas, dan terlibat dalam kegiatan ekstrakurikuler yang lebih sedikit daripada teman sebayanya (Palmer et al, 2011) yang semuanya mempengaruhi psikososial mereka. Berikut disajikan tabel psikososial terkait kesejahteraan emosi pada anak penyandang disabilitas.

Tabel 2: Domain psikososial kesejahteraan emosional

\begin{tabular}{|c|c|c|}
\hline $\begin{array}{c}\text { KELOMPO } \\
\text { K USIA / } \\
\text { AREA } \\
\text { FOKUS } \\
\end{array}$ & $\begin{array}{l}\text { ISU-ISU UNTUK ANAK- } \\
\text { ANAK PENYANDANG } \\
\text { DISABILITAS }\end{array}$ & $\begin{array}{c}\text { INTERVENSI } \\
\text { PSIKOSOSIAL YANG } \\
\text { RELEVAN }\end{array}$ \\
\hline $\begin{array}{l}0-6 \\
\text { tahun }\end{array}$ & $\begin{array}{l}\text { - Anak-anak } \\
\text { penyandang } \\
\text { disabilitas } \\
\text { seperti semua } \\
\text { anak } \\
\text { membutuhkan } \\
\text { stimulasi, cinta } \\
\text { dan perawatan } \\
\text { dari pengasuh } \\
\text { yang konsisten. } \\
\text { Seorang anak } \\
\text { penyandang } \\
\text { cacat mungkin } \\
\text { gagal } \\
\text { memberikan } \\
\text { sinyal yang } \\
\text { dapat dengan } \\
\text { mudah } \\
\text { ditafsirkan oleh } \\
\text { pengasuh } \\
\text { sehingga dapat } \\
\text { pergi tanpa } \\
\text { mendapatkan } \\
\text { perhatian } \\
\text { emosional atau }\end{array}$ & 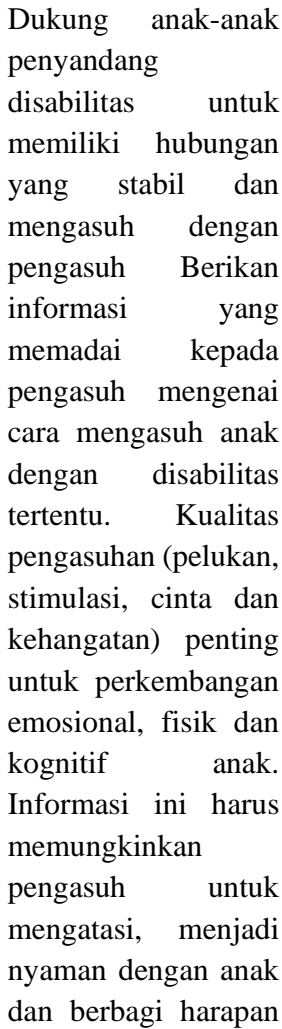 \\
\hline
\end{tabular}

\begin{tabular}{|c|c|c|}
\hline & $\begin{array}{l}\text { fisik yang } \\
\text { diperlukan } \\
\text { Beberapa anak } \\
\text { penyandang } \\
\text { cacat } \\
\text { ditinggalkan } \\
\text { oleh orang } \\
\text { tuanya. Anak- } \\
\text { anak seperti itu } \\
\text { dapat } \\
\text { dipindahkan } \\
\text { dari satu rumah } \\
\text { ke rumah } \\
\text { berikutnya } \\
\text { sehingga } \\
\text { membuat } \\
\text { mereka } \\
\text { kehilangan } \\
\text { pengasuh yang } \\
\text { konsisten. } \\
\text { Kegagalan oleh } \\
\text { pengasuh untuk } \\
\text { mengenali apa } \\
\text { yang dapat } \\
\text { dilakukan oleh } \\
\text { anak-anak } \\
\text { penyandang } \\
\text { disabilitas } \\
\text { untuk diri } \\
\text { mereka sendiri. } \\
\text { Anak-anak } \\
\text { dengan } \\
\text { disabilitas } \\
\text { dihadapkan } \\
\text { pada } \\
\text { penelantaran } \\
\text { atau pelecehan. }\end{array}$ & $\begin{array}{l}\text { untuk masa depan. } \\
\text { Tingkatkan kapasitas } \\
\text { pengasuh untuk } \\
\text { memberikan } \\
\text { perawatan bagi anak- } \\
\text { anak penyandang } \\
\text { disabilitas dengan } \\
\text { membentuk } \\
\text { kelompok pendukung } \\
\text { pengasuh. } \\
\text { Mengembangkan } \\
\text { program guna } \\
\text { melindungi anak- } \\
\text { anak yang menderita } \\
\text { disabilitas dari } \\
\text { pelecehan. }\end{array}$ \\
\hline $\begin{array}{l}7-12 \\
\text { tahun }\end{array}$ & 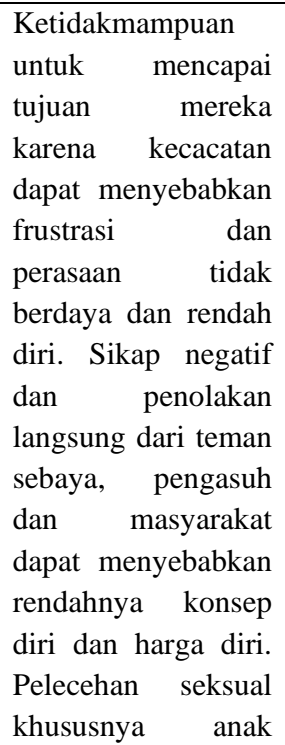 & $\begin{array}{l}\text { Program untuk } \\
\text { menyediakan } \\
\text { akses } \\
\text { pendidikan. } \\
\text { Pendidikan } \\
\text { membawa } \\
\text { kemandirian. } \\
\text { Kegiatan } \\
\text { sekolah harus } \\
\text { mencakup } \\
\text { program } \\
\text { penyadaran } \\
\text { sehingga sikap } \\
\text { negatif } \\
\text { terhadap } \\
\text { disabilitas } \\
\text { dapat ditangani } \\
\text { di sekolah. }\end{array}$ \\
\hline
\end{tabular}




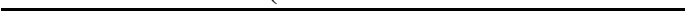

\begin{tabular}{|c|c|}
\hline $\begin{array}{l}\text { perempuan } \\
\text { penyandang } \\
\text { disabilitas }\end{array}$ & $\begin{array}{l}\text { Dapat juga } \\
\text { mencakup } \\
\text { kegiatan yang } \\
\text { melibatkan } \\
\text { kesadaran } \\
\text { keluarga dan } \\
\text { masyarakat } \\
\text { untuk melawan } \\
\text { stigma dan } \\
\text { mendorong } \\
\text { penerimaan } \\
\text { APD. } \\
\text { Mempromosika } \\
\text { n partisipasi } \\
\text { yang berarti } \\
\text { dari Anak-anak } \\
\text { penyandang } \\
\text { disabilitas dan } \\
\text { menghormati } \\
\text { pandangan } \\
\text { mereka, } \\
\text { sebagai } \\
\text { kelompok yang } \\
\text { memiliki } \\
\text { pengetahuan } \\
\text { penting seputar } \\
\text { pengalaman } \\
\text { mereka dan } \\
\text { oleh karena itu } \\
\text { sumber daya } \\
\text { terbaik untuk } \\
\text { memahami } \\
\text { pendekatan } \\
\text { untuk } \\
\text { mengatasi } \\
\text { kebutuhan } \\
\text { mereka. } \\
\text { Kembangkan } \\
\text { program yang } \\
\text { menyediakan } \\
\text { konseling stres, } \\
\text { depresi, dan } \\
\text { trauma bagi } \\
\text { anak-anak } \\
\text { penyandang } \\
\text { disabilitas } \\
\text { Kembangkan } \\
\text { dayanan anakecehkan. remaja } \\
\text { yang sensitif } \\
\text { mentuk } \\
\text { anakung } \\
\text { dileng }\end{array}$ \\
\hline
\end{tabular}

\begin{tabular}{|c|c|c|c|}
\hline $\begin{array}{l}13-17 \\
\text { tahun }\end{array}$ & & $\begin{array}{l}\text { Pelecehan } \\
\text { seksual } \\
\text { khususnya } \\
\text { anak } \\
\text { perempuan } \\
\text { penyandang } \\
\text { disabilitas } \\
\text { Anak-anak } \\
\text { penyandang } \\
\text { disabilitas } \\
\text { yang } \\
\text { sebagian } \\
\text { besar } \\
\text { bergantung } \\
\text { pada orang } \\
\text { lain untuk } \\
\text { menyelesaika } \\
\text { n tugas akan } \\
\text { mengalami } \\
\text { kesulitan } \\
\text { untuk } \\
\text { memiliki } \\
\text { citra diri dan } \\
\text { identitas } \\
\text { yang positif. } \\
\text { Transisi dari } \\
\text { masa kanak- } \\
\text { kanak ke } \\
\text { dewasa dapat } \\
\text { menyebabka } \\
\text { n banyak } \\
\text { stres. Anak- } \\
\text { anak penyandang } \\
\text { disabilitas } \\
\text { mungkin } \\
\text { merasa } \\
\text { bahwa } \\
\text { mereka tidak } \\
\text { memiliki } \\
\text { kapasitas } \\
\text { untuk } \\
\text { mengambil } \\
\text { peran baru } \\
\text { sebagai } \\
\text { pelajar, } \\
\text { karyawan, } \\
\text { majikan, istri } \\
\text { atau suami } \\
\text { nantinya. } \\
\text { Layanan } \\
\text { pelecehan } \\
\text { yang sensitif } \\
\text { terhadap } \\
\text { disabilitas }\end{array}$ & 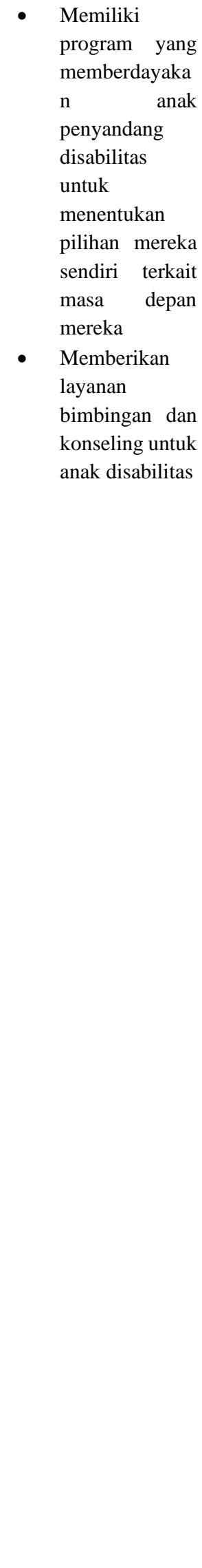 \\
\hline
\end{tabular}


Berdasarkan data pada tabel di atas, menekankan bahwa layanan pengelolaan emosi perlu ditawarkan dengan "desain universal" dan bahwa penyandang disabilitas harus "diakomodasi secara wajar". Pemaknaan "desain universal" dipahami sebagai merancang "produk, lingkungan, program, dan layanan sehingga dapat digunakan oleh semua orang, semaksimal mungkin, tanpa memerlukan adaptasi atau desain khusus".

\section{S I M P U L A N}

Seperti anak-anak lain, anak-anak penyandang disabilitas mendapat manfaat dari hubungan positif dan rasa memiliki di rumah, sekolah, dan komunitas mereka. Sayangnya, anak-anak penyandang disabilitas dapat menghadapi pengucilan sosial dan stereotip sosial yang negatif. Di beberapa budaya, kecacatan masih dipahami sebagai akibat dari sihir, kerasukan roh jahat atau hukuman spiritual dari 'dewa'. Komunitas lain menganggap anak-anak dan remaja penyandang disabilitas sebagai yang berkinerja rendah, akibatnya menuntut lebih sedikit dan menawarkan lebih sedikit kesempatan untuk berpartisipasi. Di sisi lain ada banyak contoh orang tua yang telah mendukung anak-anak mereka melawan segala rintangan dan orang tua ini menunjukkan kemampuan dan pentingnya dukungan psikososial pengasuh anak untuk perkembangan anak. Anak-anak dengan disabilitas memiliki hak atas perawatan serta dukungan sama seperti rekan-rekan mereka yang berbadan sehat yang mencakup perhatian, perawatan, stimulasi dan dukungan yang konsisten dari pengasuh utama. Selain itu, mereka mungkin memerlukan dukungan dan akomodasi tambahan untuk kebutuhan khusus mereka. Keberhasilan proses attachment memfasilitasi perkembangan identitas dan keamanan anak. Kondisi kesehatan lain tetapi juga pembatasan partisipasi dapat membuat anak bertahan dalam waktu lama di rumah yang mengakibatkan berkurangnya stimulasi dan peluang perkembangan. Selain itu anak-anak penyandang disabilitas mungkin menghadapi tantangan lain, misalnya, hambatan akses fisik ke layanan, kelalaian dan sikap negatif dari teman sebaya dan orang dewasa. Yang terakhir ini mungkin terkait dengan salah tafsir, mitos, stigma, dan kepercayaan tradisional seputar disabilitas. Reaksi masyarakat terhadap salah tafsir ini dapat mengurangi dukungan sosial dan mendorong pengucilan dan melalui pembatasan ini kesempatan untuk pendidikan, pekerjaan atau partisipasi dalam masyarakat. Faktor-faktor ini memfasilitasi isolasi anak-anak penyandang cacat yang berpotensi menyebabkan peningkatan tingkat stres dan harga diri yang lebih rendah.

\section{UCAPAN TERIMA KASIH}

Penulis ingin mengucap syukur kepada Tuhan Yang Maha Esa atas rahmat dan kasih sayang yang selalu mengalir. Kami mengucapkan terima kasih kepada orang tua dan semua yang terlibat atas keterlibatan mereka dalam studi ilmiah ini dan atas dukungan material dan moral mereka. Semoga pekerjaan ini memberi manfaat bagi semua orang yang membutuhkannya.

\section{DAFT A R PUSTAKA}

Ansell, N. and L. Young. (2004). Enabling households to support successful migration of AIDS orphans in southern Africa AIDS Care pp 3-10. 
Creswell, Jhon W. (2016). Research Design: Pendekatan Kualitatif, Kuantitatif, dan Mixed. Yogyakarta: Pustaka Belajar.

Dickman, B., Roux, A., Manson, S., Douglas, G., Shabalala, N. (2006). How could she possibly manage in court?' in Disability and social change: a South African agenda, B. Watermeyer, et al., Editors. 2006, HSRC Press Cape Town. p. 116- 133.

Hancock, Jill Hannas. (2010). Psychosocial Support for Children with Disability and their Carers. Discussion Paper Health Economics and HIV/AIDS Research Division (HEARD) University of KwaZulu-Natal.

HEARD. (2011). HEARD Disability and HIV Programme Strategy 2011-2015. Diunduh dari https://issuu.com/inforatn/docs/heard _strategy_2011_-_2015

Neubert, D. \& G. Cloerkes. (1994). Behinderung und Behinderte in verschiedenen Kulturen. Eine vergleichende Analyse ethnologischer Studien. Heidelberg: Schindele

Palmer S., Heyne L, Montie J, Abery B, and Gaylord V. (Eds.). (2011). Supporting the Social Wellbeing of Children and Youth with Disabilities, Impact. Diunduh dari http://ici.umn.edu/products/impact/24 1/default.html

Saskatchewan School Trustees Association. (n.d.). Effects of Disability on Psychosocial Development: Infancy to Adolescence. SSTA Research Report \#91-05.

Sloper, P. dan S. Turner. (1993). Risk and resistance factors in the adaptation of children with severe physical disability. Journal of Child Psychology and Psychiatry.

Sugiyono. (2016). Metode Penelitian Kuantitatif, Kualitatif, dan $R$ \& D. Bandung: PT Alfabeta.

UNICEF. (2005). Child Marriage A Harmful Traditional Practice. A Statistical Exploration 2005. New York: UNICEF.

Yeo \& Goodwin, Jenny. (2001). Two Factors Affecting Internal Audit Independence and Objectivity: Evidence From Singapore. International Journal of Auditing, Vol.5 pp 107-125.

Tiller, W., McCraty, R., dan Atkinson, M. (1996). Cardiac coherence: A new, noninvasive measure of autonomic nervous system order. Alternative Therapies in Health and Medicine, 2(1): 52-65

Kashani, J., Suarez, L., Allan, W., dan Reid, J. (1997). Hopelessness in inpatient youths: a closer look at behavior, emotional expression, and social support. Journal of the American Academy of Child and Adolescent Psychiatry, 36( 11): 1625-1631. 